\title{
Maxillary Sinus Cancer pMX TNM Finding v6
}

National Cancer Institute

\section{Source}

National Cancer Institute. Maxillary Sinus Cancer pMX TNM Finding v6. NCI Thesaurus. Code C65024.

Maxillary sinus cancer in which distant metastasis cannot be assessed. (from AJCC 6th Ed.) 